\title{
AKIBAT HUKUM IDENTITAS PALSU DALAM AKTA PERJANJIAN KREDIT YANG MELIBATKAN PIHAK KETIGA PEMBERI JAMINAN
}

\author{
Puspa Pasaribu, Eva Achjani Zulfa \\ Magister Kenotariatan Fakultas Hukum Universitas Indonesia, Depok \\ puspa.pasaribu@ui.ac.id
}

\begin{abstract}
Abstrak
Penelitian ini bertujuan untuk mengetahui akibat hukum identitas palsu debitur dalam akta notaris mengenai perjanjian kredit terhadap pihak ketiga pemberi jaminan serta upaya hukum yang dapat ditempuh untuk membatalkan akta notaris tersebut. Notaris seyogyanya teliti dan berhati-hati dalam membuat akta autentik, terlebih mengenai perjanjian kredit yang melibatkan pihak ketiga pemberi jaminan. Sebab, pihak ketiga pemberi jaminan memiliki kepentingan yang berbeda dengan debitur atau kreditur. Jika debitur secara beritikad buruk memberikan identitas palsu dalam suatu perjanjian, maka akibat hukum adanya identitas palsu tersebut perlu dianalisis dari perspektif Pasal 1320 KUHPerdata. Penelitian ini diharapkan dapat memberikan jalan keluar terkait perlindungan serta kepastian hukum bagi pihak ketiga pemberi jaminan. Penelitian ini menggunakan pendekatan yuridis normatif dengan menggunakan data sekunder melalui studi dokumen dan penelusuran literatur. Penelitian ini memiliki kebaharuan perspektif karena menganalisis akibat hukum identitas palsu dalam akta notaris terhadap pihak selain debitur dan kreditur, yakni pihak ketiga pemberi jaminan. Hasil penelitian ini menyimpulkan bahwa akibat hukum yang timbul terhadap suatu akta dengan identitas palsu adalah dapat dibatalkan karena terdapat penipuan di dalamnya, sebagaimana diatur dalam Pasal 1321 KUHPerdata. Penipuan mengakibatkan perjanjian dalam akta tersebut tidak memenuhi syarat subjektif berupa kesepakatan yang bebas berdasarkan Pasal 1320 KUHPerdata. Namun, untuk membatalkan akta notaris tersebut, penipuan harus terbukti dan tidak dapat dipersangkakan. Oleh karena itu, sangat penting untuk memperoleh putusan pidana berkekuatan hukum tetap yang membuktikan adanya penipuan agar gugatan pembatalan akta memiliki dasar yang kuat. Sebaliknya, akta tersebut tidak dapat dibatalkan jika unsur penipuannya tidak terbukti sehingga masih menjadi akta autentik dan tetap mengikat.
\end{abstract}

Kata kunci: Autentik; Kredit; Notaris

\section{LEGAL CONSEQUENCES OF FALSE IDENTITY IN A CREDIT AGREEMENT DEED INVOLVING THIRD PARTY SECURITY}

\begin{abstract}
This study aims to analyze the legal consequences of an authentic deed regarding credit agreement that contains false identity of the debtor towards the third party security and the pursuable legal efforts to cancel that deed. Notaries bear the responsibility of being thorough and careful in drafting authentic deeds, especially regarding credit agreement that involves a third party security. This is because third party securities have different interests from those of the debtor or creditor. If a debtor purposely gives false identity in an agreement in bad faith, the legal consequences will need to be analyzed pursuant to Article 1320 of the Indonesian Civil Code (ICC). The study utilizes juridical-normative methods, using secondary data through literature study. This study hopes to offer a solution regarding the legal protection and legal certainty of the third party security. This study offers a new perspective by analyzing the legal consequences of false identity towards third party security, instead of towards the debtor or creditor. This study concludes that an authentic deed containing false identity is voidable due to fraud, pursuant to Article 1321 of the ICC. The presence of fraud in an agreement renders it voidable for not conforming to Article 1320 of the ICC. However, that fraud must be proven by a criminal court decision. Acquiring a criminal verdict that proves the presence of fraud in an agreement is essential in cancelling the authentic deed of that agreement. Otherwise, the authentic deed will remain valid and binding if fraud is not proven.
\end{abstract}

Keywords: Authentic; Credit; Notary 
e-ISSN : 2621-4105

\section{A. PENDAHULUAN}

Notaris senantiasa harus teliti dan berhati-hati dalam menjalankan profesinya, terutama dalam membuat suatu akta autentik. Sebagai pejabat umum yang telah mendapatkan jabatan kepercayaan dari masyarakat, notaris diwajibkan melaksanakan profesinya dengan sebaik-baiknya dan senantiasa menjunjung tinggi etika hukum. ${ }^{1}$ Sebab, akibat hukum yang ditimbulkan oleh akta autentik mengikat para pihak yang tercantum dalam akta tersebut. Ditambah lagi, dalam hal terjadinya sengketa antara para pihak, akta autentik merupakan alat bukti yang memiliki kekuatan pembuktian sempurna dalam proses persidangan. Kekuatan pembuktian yang sempurna artinya adalah akta autentik merupakan alat bukti yang terpenuh dan terkuat ${ }^{2}$ serta melingkupi nilai kekuatan pembuktian materiil, formal, dan lahiriah. ${ }^{3}$ Selain itu, akta autentik juga penting dalam menjaga kepastian hukum dalam suatu perjanjian. Dalam dunia hukum, salah satu aspek paling esensial adalah kepastian hukum, yakni hukum bertujuan untuk menjamin kepastian dalam hubungan antarsubjek di masyarakat. ${ }^{4}$ Memandang perkembangan hukum di masyarakat dewasa ini, kebutuhan akan akta autentik untuk menjamin kepastian hukum tersebut kian meningkat. Masyarakat semakin sadar akan akibat hukum dalam membuat dan melaksanakan suatu perjanjian dengan subjek hukum lain. Akta autentik menjadi salah satu pilihan dalam merumuskan hak dan kewajiban para pihak dengan jelas sehingga menjamin kepastian hukum. Selain itu, akta autentik juga berperan sebagai alat untuk memperjuangkan keadilan bagi para pihak yang membuatnya.

Sebagaimana telah diatur dalam Undang-Undang No. 30 Tahun 2004 juncto Undang-Undang Nomor 2 Tahun 2014 tentang Jabatan Notaris ("UUJN"), notaris adalah pejabat umum yang telah diberikan kewenangan membuat akta autentik. Kewenangan notaris tersebut tercantum pula dalam Pasal 1868 Kitab Undang-Undang Hukum Perdata ("KUHPerdata") yang menyatakan bahwa akta autentik adalah akta yang dibuat oleh atau di hadapan pejabat umum yang berwenang. Lebih khusus lagi, Pasal 15 ayat (1) UUJN menyatakan bahwa notaris berwenang membuat akta autentik mengenai sebuah perbuatan, perjanjian dan ketetapan yang diharuskan. ${ }^{5}$

Oleh karena itu, sudah seharusnya notaris berhati-hati dalam menuangkan semua perbuatan, perjanjian, dan penetapan yang diharuskan oleh peraturan perundangundangan dan/atau yang dikehendaki oleh yang berkepentingan ke dalam akta autentik. Dalam bukunya, G.H.S. Lumban Tobing menguraikan kewenangan notaris sebagai berikut:

${ }^{1}$ Edwar Edwar, Faisal A Rani, and Dahlan Ali, "Kedudukan Notaris Sebagai Pejabat Umum Ditinjau Dari Konsep Equality Before the Law," Jurnal Hukum \& Pembangunan 49, no. 1 (2019): 187-201, https://doi.org/10.21143/jhp.vol49.no1.1916.

${ }^{2}$ Maimunah Nurlete, Winanto Wiryomartani, and Widodo Suryandono, "Tanggung Jawab Notaris Terhadap Akta Palsu Berdasarkan Pelanggaran Norma Dan Sanksinya (Studi Kasus Putusan Pengadilan Negeri Tanjung Karang Nomor 244/Pid. B/PN.TJK)," Indonesian Notary 2, no. 3 (2020): 378-401.

${ }^{3}$ Komang Ayuk Septianingsih, I Nyoman Putu Budiartha, and Anak Agung Sagung Laksmi Dewi, "Kekuatan Alat Bukti Akta Otentik Dalam Pembuktian Perkara Perdata," Jurnal Analogi Hukum 2, no. 3 (November 20, 2020), https://doi.org/10.22225/ah.2.3.2584.336-340.

${ }^{4}$ Theresia Ngutra, "Hukum Dan Sumber-Sumber Hukum,” Jurnal Supremasi 11, no. 2 (2016): 193-211.

5 "Undang-Undang Nomor 2 Tahun 2014 Tentang Perubahan Atas Undang-Undang Nomor 30 Tahun 2004 Tentang Jabatan Notaris,” Pub. L. No. 2 (2014). 
"Hubungan erat antara ketentuan mengenai bentuk akta dan keharusan adanya para pejabat yang mempunyai tugas untuk melaksanakannya menyebabkan adanya kewajiban bagi penguasa untuk menunjuk dan mengangkat pejabat sedemikian. Wewenang notaris ini meliputi 4 hal yaitu:

a. Notaris harus berwenang sepanjang yang menyangkut akta yang dibuat itu;

b. Notaris harus berwenang sepanjang mengenai orang yang orang untuk kepentingan siapa akta itu dibuat;

c. Notaris harus berwenang sepanjang mengenai tempat di mana akta itu dibuat;

d. Notaris harus Berwenang sepanjang mengenai waktu pembuatan akta itu."6

Selain kewajiban yang diatur dalam Pasal 15 ayat (1) UUJN, sebagai salah satu profesi hukum, notaris juga secara implisit wajib mencegah terjadinya sengketa. ${ }^{7}$ Akta autentik memberikan suatu kontribusi nyata terhadap pencegahan atau penyelesaian suatu sengketa, baik di dalam maupun di luar pengadilan. Atas dasar ini, dalam membuat akta autentik, prinsip kehati-hatian dan ketelitian harus diindahkan oleh notaris agar tercapai kepastian, ketertiban, dan perlindungan hukum bagi para pihak yang berkepentingan, sebagaimana diwajibkan oleh peraturan perundang-undangan. Penerapan prinsip kehatihatian oleh notaris dapat memperkecil risiko suatu akta autentik dipermasalahkan atau disengketakan secara hukum, baik sekarang maupun di masa yang akan datang.

Akan tetapi, dalam praktiknya, ada kalanya perjanjian yang tertuang dalam akta autentik tersebut ternyata mengandung suatu kekhilafan, kekeliruan, bahkan penipuan. Salah satu contohnya adalah kasus Putusan Pengadilan Tinggi DKI Jakarta Nomor 140/PDT/2020/PT.DKI tertanggal 20 April 2020 jo. Putusan Pengadilan Negeri Jakarta Utara Nomor 101/Pdt.G/2015/PN.Jkt.Utr. tertanggal 16 Maret 2016. Dalam perkara ini, terdapat dugaan kejahatan berupa penipuan identitas yang dilakukan oleh debitur terhadap pihak ketiga yang bertindak sebagai pemberi jaminan. Sebelum membahas kasus tersebut lebih dalam, penelitian ini akan menguraikan beberapa penelitian sebelumnya yang terkait dengan pokok permasalahan penelitian ini.

Penelitian yang pertama berjudul "Prinsip Kehati-hatian Notaris dalam Membuat Akta Autentik” oleh Manuaba, dkk. (2018). Penelitian ini mengangkat suatu permasalahan mengenai akibat hukum dari akta notaris yang dibuat berdasarkan adanya surat palsu juga keterangan palsu. Hasil penelitiannya menyatakan bahwa akibat hukum perjanjian dalam isi akta notaris yang telah dibuat berdasarkan surat palsu serta keterangan palsu tersebut sesuai sebagaimana diatur dalam Pasal 1320 ayat (4) dan Pasal 1335 KUHPerdata, yaitu suatu perjanjian yang dibuat berdasarkan sebab yang palsu adalah batal demi hukum (nitiegbaarheid). Sehingga, akta tersebut terdegradasi kekuatan pembuktiannya dari suatu akta autentik menjadi akta di bawah tangan. Akan tetapi, kebenaran formal yang terdapat dalam akta tersebut tetaplah mengikat para pihak yang

${ }^{6}$ Armansyah, "Beneficial Ownership Dan Kewajiban Pelaporan Atas Transaksi Keuangan Mencurigakan," Jurnal Hukum 9, no. 2 (2018): 1-18.

${ }^{7}$ Septiana Zahira, “Akibat Hukum Atas Adanya Pihak Fiktif Di Dalam Akta Jual Beli (Studi Putusan Pengadilan Negeri Jakarta Utara Nomor 845/Pid.Sus/2018/Pn.Jkt.Utr),” Indonesian Notary 3, no. 1 (2021). 
membuatnya. ${ }^{8}$ Penelitian tersebut meneliti mengenai akibat hukum suatu akta notaris dalam hal tidak terpenuhinya suatu syarat objektif perjanjian. Sedangkan, penelitian ini menganalisis tentang akibat hukum akta notaris dalam hal tidak terpenuhinya syarat subjektif dan juga melibatkan pihak ketiga sebagai pemberi jaminan.

Penelitian selanjutnya berjudul "Pertanggungjawaban Notaris Akibat Adanya Pemalsuan Identitas Diri Debitur dalam Akta Perjanjian Kredit pada Bank" oleh Aina (2016). Salah satu permasalahan yang diangkat dalam penelitian tersebut terkait dengan kedudukan akta perjanjian kredit pada suatu bank akibat adanya pemalsuan identitas diri pihak debitur. Kesimpulan dari penelitian tersebut menyatakan bahwa suatu akta perjanjian kredit memiliki kedudukan sebagai undang-undang bagi mereka yang telah membuatnya. Berdasarkan Pasal 1320 KUHPerdata, apabila ada suatu syarat perjanjian yang tidak terpenuhi, baik itu terkait dengan syarat subjektif maupun syarat objektif, maka telah terjadi cacat hukum yang menyebabkan adanya penurunan derajat akta tersebut. Sehingga, akta tersebut dapat dimintakan batal oleh para pihak yang berkepentingan atau dibatalkan oleh hakim melalui proses pengadilan. ${ }^{9}$ Perbedaan penelitian tersebut dengan penelitian ini adalah kasus yang dianalisis dalam penelitian ini tidak hanya melibatkan debitur dan kreditur, namun juga pihak ketiga sebagai pemberi jaminan.

Penelitian yang terakhir adalah penelitian dengan judul "Pembatalan oleh Hakim terhadap Akta Jual Beli yang Dibuat Berdasarkan Penipuan (Bedrog)" oleh Isnandya, dkk. (2020). Adapun permasalahan yang diangkat dalam penelitian ini adalah penipuan sebagai alasan pembatalan akta jual beli serta akibat dari pembatalan oleh hakim terhadap akta jual beli yang dibuat berdasarkan penipuan tersebut. Kesimpulan penelitian tersebut menyatakan bahwa akibat hukum yang ditimbulkan yaitu semua keadaan hukum tersebut haruslah dikembalikan seperti keadaan semula, sebagaimana saat belum terjadi suatu perbuatan hukum yang telah disebutkan dalam akta tersebut. ${ }^{10}$ Perbedaan penelitian tersebut dengan penelitian ini adalah penelitian ini menganalisis mengenai syarat subjektif yang dipalsukan terkait dengan akta kredit modal kerja. Selain itu, para pihak yang terlibat dalam pembuatan akta kredit modal kerja tersebut bukan hanya debitur dan kreditur, namun juga pihak ketiga sebagai pemberi jaminan.

Dari uraian singkat atas penelitian terdahulu (literature review) tersebut, dapat disimpulkan bahwa secara garis besar, keterbatasan penelitian-penelitian sebelumnya adalah perjanjian kredit yang diteliti hanya melibatkan dua pihak: debitur dan kreditur. Sedangkan, penelitian ini meneliti perjanjian kredit yang tidak hanya melibatkan debitur dan kreditur, namun juga melibatkan pihak ketiga atau pihak lain yang bertindak sebagai pemberi jaminan sehingga kepentingan pemberi jaminan dalam hal ini berbeda dengan kepentingan debitur maupun kreditur. Oleh karena itu, penelitian ini dibuat untuk

\footnotetext{
${ }^{8}$ Ida Bagus Paramaningrat Manuaba, I Wayan Parsa, and I Gusti Ketut Ariawan, "Prinsip Kehati-Hatian Notaris Dalam Membuat Akta Autentik," Acta Comitas 3, no. 1 (2018): 59-74, https://doi.org/10.24843/AC.2018.v03.i01.p05.

${ }^{9}$ Nurul Aina, "Pertanggung Jawaban Notaris Akibat Adanya Pemalsuan Identitas Diri Debitor Dalam Akta Perjanjian Kredit Pada Bank," Premise Law Jurnal 11 (2016): 1-14.

${ }^{10}$ Eva Riska Isnandya, Rosa Agustina, and Arsin Lukman, "Pembatalan Oleh Hakim Terhadap Akta Jual Beli Yang Dibuat Berdasarkan Penipuan (Bedrog)," Indonesian Notary 2, no. 3 (2020): 209-31.
} 
memecahkan keterbatasan tersebut (state of the art). Permasalahan inti dari penelitian ini adalah debitur ternyata memiliki identitas palsu, sementara akta perjanjian modal kerja telah dibuat dan dilaksanakan, bahkan dananya telah dicairkan kepada debitur. Debitur tersebut melarikan diri dari kewajibannya dan keberadaannya tidak diketahui, sementara pihak yang memberikan jaminan menjadi korban atas identitas palsu debitur. Oleh karena itu, penelitian ini bertujuan untuk menganalisis akibat hukum akta notaris yang memuat identitas palsu tersebut terhadap pihak ketiga pemberi jaminan, serta upaya hukum yang dapat ditempuh pihak ketiga tersebut dalam membatalkan akta notaris tersebut.

\section{B. PERMASALAHAN}

1. Bagaimana akibat hukum akta notaris yang memuat identitas palsu ditinjau dari syarat sah perjanjian berdasarkan Pasal 1320 KUHPerdata?

2. Bagaimana upaya hukum pihak ketiga sebagai pemberi jaminan dalam membatalkan akta notaris yang memuat identitas palsu debitur?

\section{METODE PENELITIAN/LANDASAN TEORITIS}

Metodologi pada hakikatnya merupakan suatu unsur yang mutlak harus ada di dalam suatu penelitian dan pengembangan ilmu pengetahuan. Berdasarkan uraian rumusan masalah yang dipaparkan, dapat disimpulkan bahwa penelitian ini merupakan penelitian yuridis normatif. Penelitian yuridis normatif adalah penelitian hukum yang bertujuan untuk melakukan penelitian yang pada dasarnya menganalisis asas-asas hukum, sistematika hukum, taraf sinkronisasi hukum, perbandingan, dan sejarah hukum. Mengingat bahwa penelitian ini bertujuan menganalisis akibat hukum identitas palsu debitur dalam suatu akta kredit yang melibatkan pihak ketiga sebagai penjamin, maka bentuk penelitian yang tepat untuk mencapai tujuan tersebut adalah penelitian yuridis normatif.

Pada penelitian yuridis normatif, bahan pustaka merupakan data dasar yang dapat digolongkan sebagai data sekunder. Guna mencapai tujuan penelitian ini, pengumpulan data dilakukan dengan cara studi dokumen atau penelusuran kepustakaan. Penelitian dilakukan dengan cara menganalisis isi (content analysis) untuk menemukan pesan dan maksud yang terkandung di dalam dokumen tersebut. Pengumpulan data-data dilakukan melalui penelusuran bahan kepustakaan, maka data-data yang dipergunakan di dalam penelitian ini adalah data sekunder. Penelusuran kepustakaan tersebut dilakukan terhadap buku-buku teks dan peraturan perundang-undangan terkait dengan jabatan notaris, serta karya-karya ilmiah seperti jurnal, tesis, dan artikel ilmiah. Bahan-bahan kepustakaan tersebut diperoleh dari koleksi perpustakaan dan juga pusat-pusat dokumentasi daring. Data yang diperoleh dalam penelitian ini berasal dari literatur dan dokumen-dokumen untuk membantu menelaah norma-norma hukum terkait dengan jabatan notaris. Literatur yang dijadikan referensi dalam penelitian ini sebagian besar merupakan literatur dalam negeri. 


\section{HASIL DAN PEMBAHASAN}

\section{Akibat Hukum Akta Notaris yang Memuat Identitas Palsu}

Perjanjian menjadi instrumen bagi para pihak yang memiliki kepentingan untuk mengikatkan diri antara pihak yang satu dengan yang lainnya agar terpenuhi hak dan kewajiban masing-masing pihak. Selain itu, hukum perjanjian pun juga mengatur asas kebebasan berkontrak, yakni suatu asas yang menyatakan bahwa para pihak dapat menentukan sendiri kepentingan-kepentingan mereka dalam perjanjian yang telah dibuat tersebut. ${ }^{11}$ Selain itu, perjanjian juga merupakan salah satu sumber lahirnya suatu perikatan. Mengenai sumber-sumber perikatan, Subekti menjelaskan bahwa perikatan dapat timbul ataupun lahir dari suatu perjanjian ataupun dari ketentuan peraturan perundang-undangan. ${ }^{12}$

Keabsahan suatu perjanjian di Indonesia mengacu pada beberapa syarat yang diatur dalam KUHPerdata. Sebagaimana tercantum dalam Pasal 1320 KUHPerdata, syarat sahnya suatu perjanjian meliputi 4 hal, antara lain:

1. Kesepakatan dari para pihak yang mengikatkan diri;

2. Kecakapan para pihak tersebut untuk membuat perjanjian/melakukan perbuatan hukum tertentu;

3. Perjanjian berkenaan dengan suatu hal tertentu;

4. Perjanjian didasarkan pada sebuah sebab yang halal/tidak melanggar undangundang $;{ }^{13}$

Butir 1 dan 2 merupakan syarat yang berkaitan dengan para pihak yang membuat perjanjian, yakni kesepakatan di antara para pihak tersebut serta kecakapan para pihak untuk melakukan perbuatan hukum. Syarat mengenai pihak ini dikenal juga dengan syarat subjektif. Sementara itu, butir 3 dan 4 mengatur mengenai objek perjanjian yang harus spesifik dan sebab dilakukannya perjanjian yang harus sesuai dengan peraturan perundang-undangan yang berlaku. Syarat ini disebut juga dengan syarat objektif.

Jika suatu perjanjian tidak memenuhi syarat subjektif, maka perjanjian tersebut dapat dibatalkan (voidable). Perjanjian yang tidak memenuhi salah satu syarat subyektif akan mengakibatkan perjanjian itu tidak sah sehingga dapat diminta dibatalkan (canceling) oleh salah satu pihak. ${ }^{14}$ Artinya, pihak yang merasa dirugikan dapat meminta pembatalan perjanjian tersebut kepada hakim melalui proses pengadilan. ${ }^{15}$ Sedangkan, jika suatu perjanjian tidak memenuhi syarat objektif, maka

11 Togi Pangaribuan, "Permasalahan Penerapan Klausula Pembatasan Pertanggungjawaban Dalam Perjanjian Terkait Hak Menuntut Ganti Kerugian Akibat Wanprestasi," Jurnal Hukum \& Pembangunan 49, no. 2 (July 5, 2019): 443-54, https://doi.org/10.21143/jhp.vol49.no2.2012.

${ }^{12}$ Subekti, Pokok-Pokok Hukum Perdata (Jakarta: Intermasa, 2003).

${ }^{13}$ Rizky Amalia, Musakkir Musakkir, and Syamsuddin Muchtar, "Pertanggungjawaban Notaris Terhadap Isi Akta Autentik Yang Tidak Sesuai Dengan Fakta," Al-Ishlah 24, no. 1 (2021): 188-206.

${ }^{14}$ Tesalonika Marta Ayuning Tyas and Adi Sulistiyono Pranoto, "Pembatalan Akta Perjanjian Kredit Karena Objek Jaminan Tidak Sah (Analisis Putusan Pengadilan Negeri Bandung Nomor 496/Pdt.G/2014/PN Bdg), Jurnal Repertorium 4, no. 2 (2017): 103-9.

15 Tyas and Pranoto. 
perjanjian tersebut batal demi hukum (null and void) dan dianggap tidak pernah ada, tanpa perlu adanya permintaan pembatalan ke pengadilan.

Dalam kasus Putusan Pengadilan Tinggi DKI Jakarta Nomor 140/PDT/2020/PT.DKI tertanggal 20 April 2020 jo. Putusan Pengadilan Negeri Jakarta Utara Nomor 101/Pdt.G/2015/PN.Jkt.Utr. tertanggal 16 Maret 2016, debitur sebagai salah satu pihak dalam perjanjian kredit modal kerja diduga mencantumkan identitas palsu dalam akta notaris perjanjian tersebut. Setelah dana pinjaman dari kreditur dicairkan kepada debitur, faktanya debitur sama sekali tidak membayar kewajiban cicilannya kepada kreditur. Bahkan, keberadaan debitur sama sekali tidak diketahui. Setelah ditelusuri, ternyata terdapat dugaan kuat bahwa identitas, alamat tinggal, serta alamat usaha debitur yang tercantum dalam akta perjanjian kredit adalah palsu.

Pencantuman identitas palsu dalam suatu perjanjian dapat dikategorikan sebagai penipuan sebagaimana dimaksud dalam Pasal 1321 KUHPerdata. Akibatnya, penipuan tersebut melanggar syarat subjektif Pasal 1320 KUHPerdata butir 1 mengenai kesepakatan para pihak. Subekti mendefinisikan kata kesepakatan sebagai suatu kehendak yang bebas dalam membuat perjanjian. Kesepakatan yang berdasarkan atas kehendak bebas sebagai syarat pertama untuk suatu perjanjian yang sah dianggap tidak terpenuhi apabila kesepakatan tersebut timbul atas dasar suatu paksaan (dwang), kekhilafan (dwaling), atau penipuan. ${ }^{16}$ Hal tersebut sesuai dengan ketentuan Pasal 1321 KUHPerdata yang menyatakan bahwa kesepakatan dianggap tidak sah apabila kesepakatan tersebut diberikan atau diperoleh karena kekhilafan, paksaan, atau penipuan. $^{17}$

Penipuan didefinisikan telah terjadi apabila salah satu pihak telah secara sengaja memberikan keterangan tidak benar yang disertai dengan kelicikan sehingga pihak lain dalam perjanjian tersebut terbujuk dan kemudian memberikan kesepakatannya. ${ }^{18}$ Pembatalan atas suatu perjanjian dapat dimintakan jika kesepakatan yang bebas dalam perjanjian tidak terpenuhi, baik karena adanya kekhilafan, paksaan, atau penipuan dari salah satu pihak ketika perjanjian tersebut telah dibuat. ${ }^{19}$ Dalam kasus ini, identitas, alamat tinggal, serta alamat usaha yang diduga palsu menjadi salah satu bukti itikad tidak baik dari debitur. Ditambah lagi, jejak debitur seketika hilang dan tidak pernah diketahui lagi keberadaannya oleh penggugat sebagai pihak ketiga pemberi jaminan. Itikad buruk debitur tersebut dapat disimpulkan mengarah pada dugaan keras tindak pidana penipuan sebagaimana diatur dalam Pasal 378 Kitab Undang-Undang Hukum Pidana (KUHP). Tindak pidana penipuan tersebut telah memengaruhi kebebasan kesepakatan para pihak dalam membuat perjanjian tersebut.

\footnotetext{
${ }^{16}$ Subekti, Pokok-Pokok Hukum Perdata.

${ }^{17}$ Subekti and Tjitrosudibio, Kitab Undang-Undang Hukum Perdata [Burgerlijk Wetboek] (Jakarta: Pradnya Paramita, 2009).

${ }^{18}$ Subekti, Pokok-Pokok Hukum Perdata.

${ }^{19}$ Isnandya, Agustina, and Lukman, "Pembatalan Oleh Hakim Terhadap Akta Jual Beli Yang Dibuat Berdasarkan Penipuan (Bedrog).”
} 
Walaupun demikian, keabsahan akta notaris berbeda dengan perjanjian biasa. Akta notaris merupakan sebuah akta autentik yang dapat didefinisikan sebagai suatu akta yang berbentuk sebagaimana ditentukan oleh undang-undang, dibuat oleh atau di depan kehadiran pejabat umum yang berwenang, serta di wilayah di mana akta tersebut dibuat. $^{20}$ Jika suatu akta autentik memenuhi seluruh persyaratan dalam Pasal 1868 KUHPerdata, maka akta autentik memiliki kekuatan pembuktian yang sempurna dalam acara pengadilan perkara perdata. Artinya, jika akta autentik dipergunakan sebagai alat bukti di muka pengadilan, maka pembuktian akta tersebut cukup dengan akta itu sendiri dan dianggap benar, kecuali ada bukti lainnya yang dapat membuktikan sebaliknya. Bahkan, suatu akta autentik umumnya memang dengan sengaja dibuat dari awal perjanjian untuk kepentingan pembuktian jika timbul suatu sengketa dalam perjanjian tersebut.

Suatu akta autentik dapat mengalami kebatalan dalam dua bentuk, yakni degradasi (kehilangan kekuatan pembuktian sempurna) atau batal demi hukum/dapat dibatalkan. Degradasi terjadi ketika suatu akta memiliki cacat dalam bentuknya atau dibuat oleh notaris yang tidak berwenang atau tidak cakap. Pasal 1869 KUHPerdata menyatakan bahwa suatu akta tidak dapat dianggap sebagai akta autentik jika pejabat yang membuat akta tersebut tidak berkuasa atau tidak cakap, atau jika terdapat suatu cacat dalam bentuknya, namun akta tersebut tetap berkekuatan sebagai akta di bawah tangan jika ditandatangani oleh para pihak. ${ }^{21}$ Sedangkan, akta autentik batal demi hukum/dapat dibatalkan jika perjanjian yang mendasarinya tidak memenuhi syaratsyarat sah perjanjian sebagaimana diatur dalam Pasal 1320 KUHPerdata, baik syarat objektif (batal demi hukum) maupun syarat subjektif (dapat dibatalkan).

Dalam kasus Putusan Pengadilan Tinggi DKI Jakarta Nomor 140/PDT/2020/PT.DKI tertanggal 20 April 2020 jo. Putusan Pengadilan Negeri Jakarta Utara Nomor 101/Pdt.G/2015/PN.Jkt.Utr. tertanggal 16 Maret 2016, akta notaris yang diperkarakan diduga memuat identitas palsu dari pihak debitur. Sementara, notaris hanya mencatat segala hal yang disampaikan oleh para pihak sehingga segala keterangan palsu yang disampaikan oleh salah satu pihak tersebut bukanlah tanggung jawab notaris, melainkan murni menjadi tanggung jawab pihak pemberi keterangan tersebut. ${ }^{22}$ Oleh karena itu, identitas palsu ini bukan merupakan cacat akta dalam bentuknya (cacat formil) dari sisi notaris sebagaimana dimaksudkan dalam Pasal 1869 KUHPerdata. Melainkan, pencantuman identitas palsu tersebut menyebabkan suatu akta notaris memiliki cacat kehendak dari perjanjian yang mendasarinya; bersumber dari adanya syarat sah perjanjian yang tidak dipenuhi. Berdasarkan uraian di atas, akta notaris tersebut dapat dimintakan untuk dibatalkan dan pihak ketiga sebagai pemberi jaminan dapat mengajukan permohonan kepada pengadilan untuk membatalkan akta tersebut.

${ }^{20}$ Subekti and Tjitrosudibio, Kitab Undang-Undang Hukum Perdata [Burgerlijk Wetboek].

${ }^{21}$ Subekti and Tjitrosudibio.

22 I Wayan Erik Pratama Putra, Luh Putu Sudini, and I Nyoman Alit Puspadma, "Notary Responsibilities on the Making of Deed with Double Number," Jurnal Notariil 5, no. 1 (May 2020): 39-48. 


\section{Upaya Hukum Membatalkan Akta Notaris yang Memuat Identitas Palsu}

Sebagaimana telah diuraikan sebelumnya, suatu perjanjian kredit bisa saja tidak hanya melibatkan pihak debitur dan kreditur, namun juga melibatkan pihak lain atau pihak ketiga sebagai pemberi jaminan. Kasus Putusan Pengadilan Tinggi DKI Jakarta Nomor 140/PDT/2020/PT.DKI tertanggal 20 April 2020 jo. Putusan Pengadilan Negeri Jakarta Utara Nomor 101/Pdt.G/2015/PN.Jkt.Utr. tertanggal 16 Maret 2016, penggugat berkedudukan sebagai pihak ketiga pemberi jaminan yang menjaminkan utang debitur dengan jaminan Hak Tanggungan terhadap tanah dan bangunan milik penggugat. Pada faktanya, penggugat tidak mengenal baik debitur, namun penggugat tetap bersedia memberikan jaminan Hak Tanggungan tersebut melalui suatu Surat Kuasa Membebankan Hak Tanggungan (SKMHT). Setelah adanya SKMHT, dibuat suatu Akta Pembebanan Hak Tanggungan sesuai dengan tenggang waktu yang tidak melebihi 3 (tiga) bulan. Hak Tanggungan tersebut kemudian didaftarkan oleh Pejabat Pembuat Akta Tanah (PPAT) ke kantor pertanahan. Sebagai bukti telah dilekatkannya Hak Tanggungan, Kantor Pertanahan menerbitkan Sertifikat Hak Tanggungan.

Sebagaimana diketahui, sebuah Sertifikat Hak Tanggungan memuat irah-irah "Demi Ketuhanan Yang Maha Esa" sehingga memiliki titel eksekutorial yang sama dengan suatu putusan pengadilan yang memperoleh kekuatan hukum tetap. Artinya, kreditur berhak untuk mengeksekusi langsung objek Hak Tanggungan atas kekuasaan sendiri (parate executie). Dengan demikian, jika debitur tidak mampu membayar utangnya kepada kreditur, maka kreditur berhak secara langsung mengeksekusi tanah dan bangunan yang menjadi objek jaminan tersebut tanpa putusan pengadilan. Mengingat debitur tidak pernah membayar kewajibannya kepada kreditur dan bahkan menghilang tanpa jejak, penggugat sebagai pihak ketiga pemberi jaminan tentu menginginkan akta notaris perjanjian kredit tersebut batal untuk mencegah eksekusi tanah dan bangunan miliknya.

Walaupun demikian, perjanjian yang terjadi karena penipuan tidak bisa serta merta dibatalkan sepihak ataupun dianggap batal demi hukum. Pasal 1449 KUHPerdata mengatakan bahwa perikatan-perikatan yang dibuat dengan paksaan, kekhilafan, atau penipuan, menerbitkan suatu tuntutan untuk membatalkannya. Dari rumusan pasal tersebut, dapat diperhatikan pula bahwa suatu perikatan yang dilakukan berdasarkan penipuan tidak otomatis batal demi hukum (null and void), namun hanya menimbulkan suatu tuntutan untuk membatalkannya. R. Subekti juga menyatakan bahwa jika kesepakatan telah diberikan tidak secara bebas, maka perjanjian tersebut cacat sehingga dapat dibatalkan oleh hakim atas permintaan pihak yang telah memberikan sepakatnya tidak secara bebas. Lebih lanjut lagi, Pasal 1328 ayat (2) KUHPerdata mendalilkan bahwa suatu penipuan yang mendasari suatu perjanjian tidak boleh dipersangkakan, melainkan harus dibuktikan. Selain itu, penipuan tersebut juga harus sedemikian rupa sehingga jelas dan nyata bahwa pihak yang lain tidak akan membuat perjanjian tersebut jika penipuan tersebut tidak dilakukan. Kesepakatan para 
pihak merupakan syarat subjektif perjanjian, maka tidak dipenuhinya syarat tersebut tidak otomatis membuat perjanjiannya batal demi hukum, namun dapat diminta dibatalkan (voidable) oleh salah satu pihak. Perjanjian tersebut tetap mengikat para pihak selama tidak dimintakan batal kepada hakim oleh salah satu pihak.

Dalam konteks pembatalan akta autentik, sebagaimana telah diuraikan dalam bagian pertama, suatu akta autentik dapat mengalami kebatalan dalam dua bentuk, yakni degradasi atau batal demi hukum/dapat dibatalkan. Baik degradasi maupun batal demi hukum/dapat dibatalkannya suatu akta autentik tidak terjadi secara otomatis, melainkan harus didasarkan pada suatu putusan pengadilan yang telah berkekuatan hukum tetap. Jika akta yang tidak memenuhi syarat subjektif tersebut tidak diminta pembatalan oleh salah satu pihak, maka akta tersebut akan tetap mengikat dan menjadi undang-undang bagi para pihak yang membuatnya, sesuai dengan ketentuan Pasal 1338 KUHPerdata. ${ }^{23}$

Berdasarkan uraian di atas, dapat disimpulkan bahwa pembatalan suatu akta autentik yang didasarkan identitas palsu tidak dapat dilakukan begitu saja, namun harus digugat melalui pengadilan negeri. Identitas palsu tersebut pun harus dibuktikan secara sah dan meyakinkan sebagai suatu tindak pidana penipuan, tidak boleh dipersangkakan sebagaimana ketentuan Pasal 1328 ayat (2) KUHPerdata. Hal ini sejalan dengan pertimbangan hukum Majelis Hakim in casu yang pada pokoknya menyatakan bahwa untuk membuktikan adanya unsur penipuan yang dilakukan oleh debitur terkait dengan identitas palsu, harus terlebih dahulu diperiksa dan diadili melalui perkara pidana hingga memperoleh putusan yang berkekuatan hukum tetap. Pertimbangan hukum Majelis Hakim Putusan No. 101/Pdt.G/2015/PN.Jkt.Utr. tertanggal 16 Maret 2016 pada halaman 70 menyatakan bahwa penggugat harus membuktikan terlebih dahulu mengenai adanya suatu penipuan, dan bukti tersebut adalah adanya suatu putusan pidana tentang penipuan dari pengadilan negeri.

Pertimbangan hukum Majelis Hakim tersebut bertujuan untuk menjaga kepastian hukum dan mencegah timbulnya kerugian yang lain pada pihak lain. Selain itu, unsurunsur akta autentik yang dipermasalahkan dalam kasus ini pun telah terpenuhi sebagaimana diatur dalam Pasal 1868 KUHPerdata sebagai berikut:

1. akta autentik tersebut harus dibuat oleh atau di depan kehadiran pejabat umum;

2. akta autentik tersebut harus dibuat dalam bentuk sedemikian rupa sebagaimana telah ditentukan oleh peraturan perundang-undangan;

3. pejabat umum yang dimaksud harus memiliki wewenang untuk membuat akta autentik tersebut. ${ }^{24}$

Dalam kasus ini, untuk mengupayakan pembatalan akta autentik tersebut, penggugat sebaiknya mengajukan tuntutan secara pidana terlebih dahulu terhadap dugaan tindak pidana penipuan yang dilakukan debitur, sebagaimana yang menjadi pertimbangan hukum Majelis Hakim pada tingkat pertama yang kemudian diperkuat

${ }^{23}$ Isnandya, Agustina, and Lukman, "Pembatalan Oleh Hakim Terhadap Akta Jual Beli Yang Dibuat Berdasarkan Penipuan (Bedrog).”

${ }^{24}$ Subekti and Tjitrosudibio, Kitab Undang-Undang Hukum Perdata [Burgerlijk Wetboek]. 
pada tingkat banding. Sebelum ada putusan pidana yang berkekuatan hukum tetap terkait dengan penipuan yang dilakukan oleh debitur, maka akta notaris tersebut tidak dapat dibatalkan secara sepihak tanpa ada dasar hukum yang kuat dan mengikat. Namun, apabila debitur telah terbukti secara sah dan meyakinkan melakukan tindak pidana penipuan, maka penggugat kemudian dapat mengajukan gugatan pembatalan akta notaris tersebut dengan alasan tindak pidana penipuan dalam perjanjian sehingga syarat subjektif sahnya perjanjian tidak terpenuhi. Namun, jika tindak pidana penipuan tersebut ternyata tidak terbukti, maka akta tersebut masih menjadi akta autentik dan tetap mengikat para pihak yang membuatnya.

\section{E. PENUTUP}

Pencantuman identitas palsu dalam suatu akta notaris dapat dikategorikan sebagai suatu tindak pidana penipuan. Berdasarkan Pasal 1321 KUHPerdata, penipuan in casu identitas palsu menyebabkan kesepakatan antara para pihak tidak sah dalam perjanjian tersebut sehingga tidak memenuhi syarat subjektif perjanjian sebagaimana diatur dalam Pasal 1320 KUHPerdata. Akibat hukum yang timbul dari tidak terpenuhinya syarat subjektif ini adalah perjanjian tersebut dapat dibatalkan. Upaya hukum untuk membatalkan akta notaris yang memuat identitas palsu tersebut adalah dengan menempuh gugatan perdata ke pengadilan. Walaupun demikian, penipuan tersebut tidak boleh dipersangkakan, melainkan harus dibuktikan terlebih dahulu. Pembuktian penipuan dalam kasus ini dapat ditempuh melalui jalur pidana. Sebagai salah satu profesi hukum, notaris juga secara implisit wajib mencegah terjadinya sengketa agar bisa mengantisipasi terjadinya pembuatan akta yang memuat identitas palsu. Selain itu, notaris hendaknya secara saksama dan aktif memberikan penyuluhan hukum kepada para pihak atas akta yang akan dibuat terkait kondisi-kondisi tertentu dalam suatu transaksi yang risiko hukumnya tidak berimbang di antara para pihak. Konsekuensi yang dialami pihak ketiga pemberi jaminan dalam kasus ini menjadi berat karena pembatalan akta autentik membutuhkan proses yang lebih rumit. Apalagi, debitur yang gagal memenuhi kewajibannya menyebabkan jaminan hak tanggungan yang merupakan hak milik pihak ketiga pemberi jaminan tersebut dapat langsung dieksekusi oleh kreditur tanpa putusan pengadilan.

\section{DAFTAR PUSTAKA}

Aina, Nurul. "Pertanggung Jawaban Notaris Akibat Adanya Pemalsuan Identitas Diri Debitor Dalam Akta Perjanjian Kredit Pada Bank.” Premise Law Jurnal 11 (2016): $1-14$.

Amalia, Rizky, Musakkir Musakkir, and Syamsuddin Muchtar. "Pertanggungjawaban Notaris Terhadap Isi Akta Autentik Yang Tidak Sesuai Dengan Fakta." Al-Ishlah 24, no. 1 (2021): 188-206.

Armansyah. "Beneficial Ownership Dan Kewajiban Pelaporan Atas Transaksi Keuangan Mencurigakan.” Jurnal Hukum 9, no. 2 (2018): 1-18.

Edwar, Edwar, Faisal A Rani, and Dahlan Ali. "Kedudukan Notaris Sebagai Pejabat 
Umum Ditinjau Dari Konsep Equality Before the Law.” Jurnal Hukum \& Pembangunan 49, no. 1 (2019): https://doi.org/10.21143/jhp.vol49.no1.1916.

Isnandya, Eva Riska, Rosa Agustina, and Arsin Lukman. "Pembatalan Oleh Hakim Terhadap Akta Jual Beli Yang Dibuat Berdasarkan Penipuan (Bedrog).” Indonesian Notary 2, no. 3 (2020): 209-31.

Manuaba, Ida Bagus Paramaningrat, I Wayan Parsa, and I Gusti Ketut Ariawan. "Prinsip Kehati-Hatian Notaris Dalam Membuat Akta Autentik." Acta Comitas 3, no. 1 (2018): 59-74. https://doi.org/10.24843/AC.2018.v03.i01.p05.

Ngutra, Theresia. "Hukum Dan Sumber-Sumber Hukum." Jurnal Supremasi 11, no. 2 (2016): 193-211.

Nurlete, Maimunah, Winanto Wiryomartani, and Widodo Suryandono. "Tanggung Jawab

Notaris Terhadap Akta Palsu Berdasarkan Pelanggaran Norma Dan Sanksinya (Studi Kasus Putusan Pengadilan Negeri Tanjung Karang Nomor 244/Pid. B/PN.TJK)." Indonesian Notary 2, no. 3 (2020): 378-401.

Pangaribuan, Togi. "Permasalahan Penerapan Klausula Pembatasan Pertanggungjawaban Dalam Perjanjian Terkait Hak Menuntut Ganti Kerugian Akibat Wanprestasi." Jurnal Hukum \& Pembangunan 49, no. 2 (July 5, 2019): 443-54. https://doi.org/10.21143/jhp.vol49.no2.2012.

Putra, I Wayan Erik Pratama, Luh Putu Sudini, and I Nyoman Alit Puspadma. "Notary Responsibilities on the Making of Deed with Double Number." Jurnal Notariil 5, no. 1 (May 2020): 39-48.

Septianingsih, Komang Ayuk, I Nyoman Putu Budiartha, and Anak Agung Sagung Laksmi Dewi. "Kekuatan Alat Bukti Akta Otentik Dalam Pembuktian Perkara Perdata." Jurnal Analogi Hukum 2, no. 3 (November 20, 2020). https://doi.org/10.22225/ah.2.3.2584.336-340.

Subekti. Pokok-Pokok Hukum Perdata. Jakarta: Intermasa, 2003.

Subekti, and Tjitrosudibio. Kitab Undang-Undang Hukum Perdata [Burgerlijk Wetboek]. Jakarta: Pradnya Paramita, 2009.

Tyas, Tesalonika Marta Ayuning, and Adi Sulistiyono Pranoto. "Pembatalan Akta Perjanjian Kredit Karena Objek Jaminan Tidak Sah (Analisis Putusan Pengadilan Negeri Bandung Nomor 496/Pdt.G/2014/PN Bdg)." Jurnal Repertorium 4, no. 2 (2017): 103-9.

Undang-Undang Nomor 2 Tahun 2014 tentang Perubahan atas Undang-Undang Nomor 30 Tahun 2004 Tentang Jabatan Notaris, Pub. L. No. 2 (2014).

Zahira, Septiana. “Akibat Hukum Atas Adanya Pihak Fiktif Di Dalam Akta Jual Beli (Studi Putusan Pengadilan Negeri Jakarta Utara Nomor 845/Pid.Sus/2018/Pn.Jkt.Utr).” Indonesian Notary 3, no. 1 (2021). 